\title{
SURVIVAL AND REPLICATION OF ESCHERICHIA COLI O157:H7 INSIDE THE MICE PERITONEAL MACROPHAGES
}

\author{
Ayman Al-Mariri ${ }^{\dagger}$ \\ Department of Molecular Biology and Biotechnology, Atomic Energy Commission, Damascus Syria \\ Submitted: February 12, 2007; Returned to authors for corrections: October 17, 2007; Approved: January 20, 2008.
}

\begin{abstract}
The replication of Escherichia coli $\mathrm{O} 157: \mathrm{H} 7$ on the resident peritoneal macrophages of four mice strains (BALB/c, CD1, C57BL, and Swiss) has been investigated. Macrophagial bactericidal killing activity was estimated via studying their ability to internalize (gentamicin-protected) E. coli during 2, 4, 24, and $48 \mathrm{~h}$ assays. Host genetic background has been found to show no significant effect on the ability of resident peritoneal macrophages to kill E. coli O157:H7.
\end{abstract}

Key words: $E$. coli $\mathrm{O} 157: \mathrm{H} 7$, macrophages, mice, gentamicin.

Escherichia coli $\mathrm{O} 157: \mathrm{H} 7$ is commonly considered the most infectious bacteria causing bloody diarrhea and acute kidney failure in children that could develop into a hemolytic uremic syndrome. Enterohaemorrhagic E. coli (EHEC) comprise a group of emerging zoonotic pathogens of worldwide importance (2).

EHEC produces several recently described virulence determinants, which enables it to colonize the large bowel and cause the disease (25). Many of its virulence factors are secreted by a type III secretion system which delivers virulence factors directly into host cells (12). Another potential virulence factor is O157:H7 LPS which enhances the cytotoxicity of verotoxin or Shiga-like toxin (Stx) on human vascular endothelial cells in vitro (15). However, its effects in vivo require more investigations, and therefore researches are undoubtedly necessary in order to determine the best cell model, that could be used in vivo to explore the effects of these bacteria (21). However, the experimental data indicate that the reactive oxygen intermediates (ROIs) production represents one of the primary mechanisms conducted by host macrophages for limiting the replication of bacteria (6). It is well documented that the opsonization of the bacteria by immunoglobulin $\mathrm{G}(\mathrm{IgG})$ and the activation of macrophages by gamma interferon (IFN- $\gamma$ ), are known factors that bring about an increase in the ROI production and bactericidal activity $(9,17)$. The purpose of this article is to: (i) demonstrate the net intracellular replication; (ii) assess the ability of E. coli $\mathrm{O} 157: \mathrm{H} 7$ strain to resist inside mice macrophages; and (iii) determine the concentration of the gentamicin that eliminates the extracellular bacteria, without affecting intracellular bacteria.

\section{Mice strains}

Specific-pathogen-free 8-weeks-old female BALB/c, C57BL/ 6 (Inbred), CD-1, and Swiss (Outbred); purchased from Charles River Laboratories (France); were used. Groups of 7 or 8 mice were housed in polypropylene cages with sterilized bedding under controlled conditions; temperature $\left(24 \pm 1^{\circ} \mathrm{C}\right)$, and relative humidity (55\%); and maintained on a standard diet and sterilized water. Water bottles were replaced daily.

\section{Bacterial strains}

E. coli (serotype $\mathrm{O} 157: \mathrm{H} 7$ ) colonies, clinically isolated from stool samples of a patient with hemorrhagic colitis, were collected during an outbreak of the disease in Damascus, Syria, in 2001. Ten well-isolated colonies that are typical for E. coli O157:H7 (i.e.: colorless, nonsorbitol fermenters) were selected and bio-chemically identified to be $E$. coli. The isolates were then confirmed by agglutination with $E$. coli $\mathrm{O} 157: \mathrm{H} 7$ antiserum coated latex test (Oxoid, UK) to ascertain $\mathrm{O} 157$ antigen presence. Positive colonies were sub-cultured on tryptical soy agar (Merck,

*Corresponding Author. Mailing address: Department of Molecular Biology and Biotechnology, Atomic Energy Commission, P.O.Box 6091, Damascus Syria. Fax: 963-11-6112289. E-mail: scientific@aec.org.sy 
Germany) and incubated for overnight at $37^{\circ} \mathrm{C}$, then screened by $\mathrm{H} 7$ latex test (Oxoid, UK).

\section{Bacterial growth conditions}

The bacteria were grown with agitation $(100 \mathrm{rpm})$ in Luria broth (LB), (Q-Biogen, Cedex, Frence) at $37^{\circ} \mathrm{C}$ for $6 \mathrm{~h}$ using $2 \%$ of an overnight culture, bacteria were harvested by centrifugation $(6,000 \times g$ for $10 \mathrm{~min})$, and re-suspended in sterile phosphatebuffered saline (PBS, $\mathrm{pH}$ 7.4). The bacterial concentration (CFU) was estimated by optical density (OD) value at $600 \mathrm{~nm}$ and adjusted to the desired concentration of $10^{9} \mathrm{CFU} / \mathrm{ml}$.

\section{Survival and replication of the $E$. coli strains in cultured murine macrophages}

Six to 8-weeks old female BALB/c, C57BL6J, CD1, and Swiss mice were euthanized by isoflurane overdose. Immediately following euthanasia, cells from the peritoneal cavity were harvested by washing using $8 \mathrm{ml}$ of Dulbecco's minimal essential medium (DMEM), (Biochrom AG, Berlin, Germany) supplemented with $5 \%$ fetal calf serum (FCS), (Eurolone, UK) and $5 \mathrm{U} / \mathrm{ml}$ heparin. Total cell numbers and viability were determined using the $[0.0003 \% \mathrm{wt} / \mathrm{vol}]$ acridine orange, (Caledon, Canda) with ethidium bromide (Eurolone, UK) [0.001\% wt/vol] exclusion technique. Explanted cells were then cultured at a density of $10^{5}$ cells per well in sterile 24-well micro plates (TPP, Switzerland) in DMEM supplemented with $5 \% \mathrm{FCS}$ and $5 \mu \mathrm{g} / \mathrm{ml}$ gentamicin (Biochrom AG, Berlin, Germany). After overnight incubation at $37^{\circ} \mathrm{C}$ in $5 \%$ $\mathrm{CO}_{2}$, cell cultures were enriched with macrophages by eliminating no adherent cells. Cells were infected either with $E$. coli $\mathrm{O} 157: \mathrm{H} 7$, or with E. coli DH5a at a multiplicity of infection of 100 bacteria per cell for $45 \mathrm{~min}$ at $37^{\circ} \mathrm{C}$ to allow the phagocytosis of the $E$. coli. After $45 \mathrm{~min}$, free cell culture media (without FCS) were removed and replaced by DMEM supplemented with 5\% FCS and $50 \mu \mathrm{g} / \mathrm{ml}$ of gentamicin, then incubated at $37^{\circ} \mathrm{C}$ with $5 \% \mathrm{CO}_{2}$ continued for $1 \mathrm{~h}$ to kill all remaining extracellular $E$. coli. The macrophages were then washed with PBS supplemented with $5 \%$ FCS and maintained thereafter in DMEM with 5\% FCS and $5 \mu \mathrm{g} / \mathrm{ml}$ of gentamicin. Cell culture media were replaced with fresh media every $24 \mathrm{~h}$. Immediately after platting, parallel experiments were performed to examine the effects of cultured macrophages treated with either (i) $25 \mathrm{U} / \mathrm{ml}$ of IFN- $\gamma$ (PAN, Biotech, Germany); (ii) the mice anti-E. coli serum; or (iii) a combination of IFN- $\gamma$ and mice anti-E. coli serum, on the capacity of phagocytes to kill intracellular E. coli O157:H7.

\section{Intracellular viability assay of $E$. coli strains in macrophages}

Macrophages and E. coli were grown in a prepared medium for $30 \mathrm{~min}$, the lamina wells were washed several times with Hanks solution, and $200 \mu$ l of the growing medium were added. This medium contains $10 \%$ FCS with $5,10,50$ or $100 \mu \mathrm{g} / \mathrm{ml}$ of gentamicin. Two, 24, and $48 \mathrm{~h}$ after infection, macrophages were washed with PBS supplemented with 5\% FCS and lysed with
$0.2 \%$ Triton X-100. Five minutes after incubation at room temperature, serial 10-fold dilutions of the lysates were prepared in sterile PBS and plated on LBA and incubating at $37^{\circ} \mathrm{C}$ for overnight. Platting was performed in triplicate from 3 wells per strain each time. Data obtained were expressed as $\log _{10}$ intracellular E. coli.

\section{Statistical analysis}

Data were analyzed using the Student's two-tailed $t$ test (Abacus Concepts, 1994). All statistical comparisons were considered significant at the 5\% probability level.

The presence of gentamicin at 5 or $10 \mu \mathrm{g} / \mathrm{ml}$ concentrations has no effect on the counts of the intracellular bacteria after 2 or $4 \mathrm{~h}$ of incubating periods, compared with cultures incubated without antibiotic. In contrast, the presence of gentamicin at 50 or $100 \mu \mathrm{g} / \mathrm{ml}$ concentrations decreased the intracellular bacterial counts, for both incubation times, by 20 to 30 folds. Therefore, a dose of $5 \mu \mathrm{g} / \mathrm{ml}$ of gentamicin was used to incubate the macrophages and E. coli, because it eliminates the extracellular bacteria without affecting intracellular bacteria.

Fig. 1 shows that the E. coli $\mathrm{O} 157: \mathrm{H} 7$ bacterial colonies were slightly increased in C57BL strain compared to BABL/c strain particularly after $2 \mathrm{~h}$ of post-infection $(p<0.0005)$. The bacterial count in these two strains was identical for the $E$. coli O157:H7 ampicillin-resistant or susceptible strains.

The bacterial count, 2 , and $24 \mathrm{~h}$ after infection, was slightly higher in Swiss strain compared with CD1 strain (Fig. 2). In contrast, after $4 \mathrm{~h}$ the bacterial count was higher in CD1 than the Swiss mice $(p<0.05)$ (Fig. 2). However, it remained unchanging in the other mice strains (BALB/c, Swiss, CD1 and C57BL), after $48 \mathrm{~h}$ of infection (Figs. 1, 2). On the other hand, the bacterial count increased in accordance with the time of macrophage infection in all mice strains, but the lethal effect of macrophage reversely decreased to bacterial exposure time.

The data concerning the lethal effect of macrophages did not reveal any differences in bacterial counts either before or after adding the serum containing antibodies against the $E$. coli, or the gamma interferon (data not shown).

Ampicillin-resistant E. coli $\mathrm{O} 157: \mathrm{H} 7$, and E. coli $\mathrm{DH} 5$ a which is a non pathogenic strain, did not both stimulate the macrophages apoptosis $24 \mathrm{~h}$ after infection in all mice strains (data not shown). Macrophage is considered the major constituent of the natural immunity system. It can specify the antigens in large groups of bacteria and differentiate it from self antigens, and can also activate the procedures of bacterial elimination within host body. The phagocytic response of innate immune cells such as macrophages is defined by the activation of complex signaling networks that are stimulated by microbial contact (13). Phagocytosis has served as the classic model of microbe-innate immune interactions, and enormous progress has been made toward understanding the consequences of this interaction (10). 


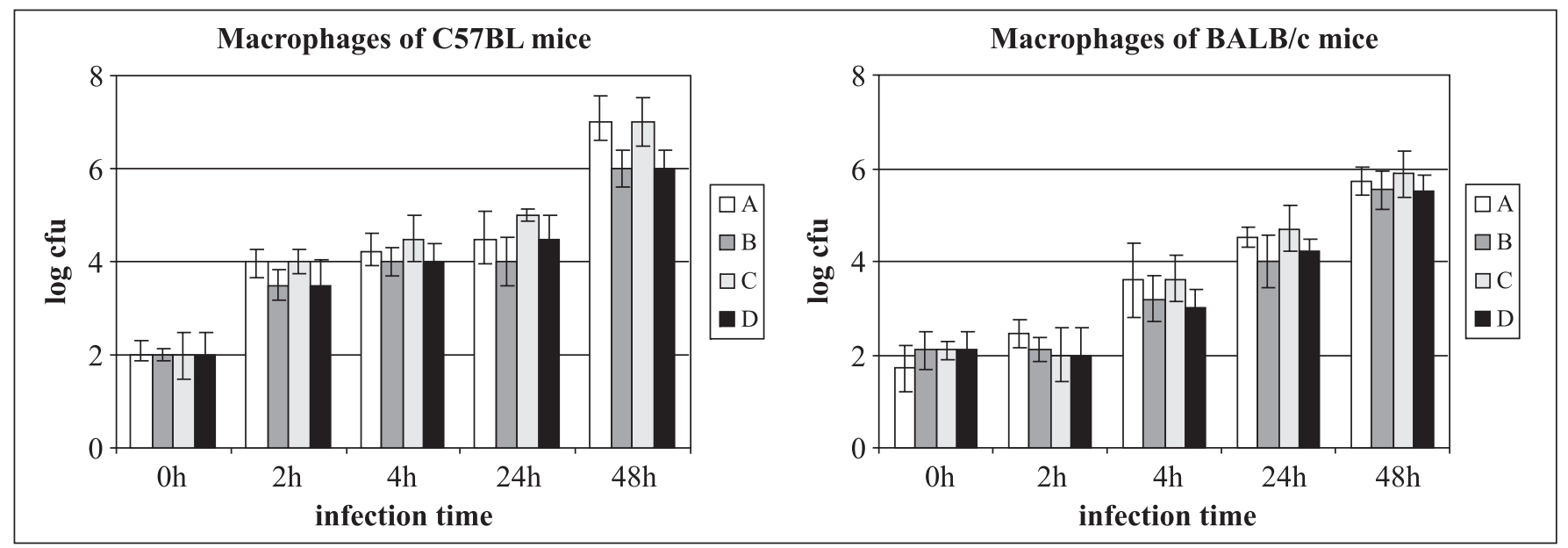

Figure 1. Intracellular survival and replication of E. coli $\mathrm{O} 157: \mathrm{H} 7$ in primary cultures of resident peritoneal macrophages from inbred mice. A and B: E. coli O157:H7 susceptible to ampicillin (A. untreated macrophages, B. macrophages treated with $5 \mu \mathrm{g} / \mathrm{ml}$ gentamicin). C and D: E. coli O157:H7 resistant to ampicillin (C. untreated macrophages, D. macrophages treated with $5 \mu \mathrm{g} / \mathrm{ml}$ gentamicin). The error bars represent the standard deviation in an average of $\log _{10}$ intracellular E. coli $\mathrm{O} 157: \mathrm{H} 7$ from triplicate platting taken at each time.

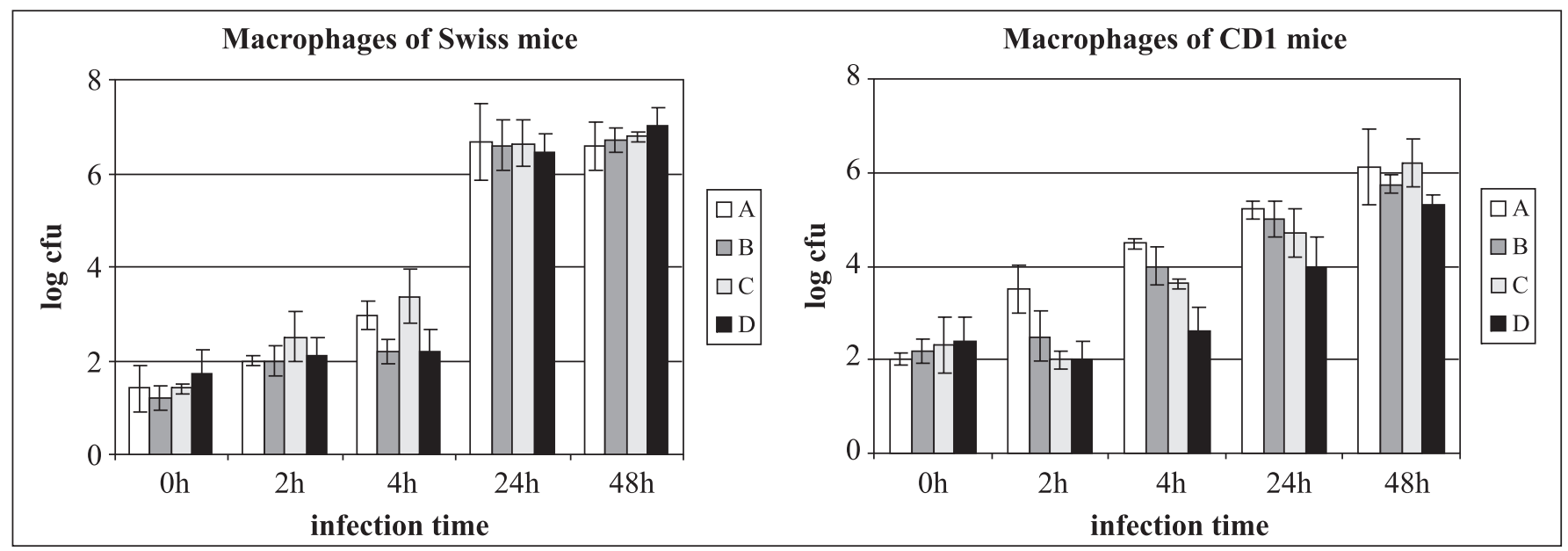

Figure 2. Intracellular survival and replication of $E$. coli $\mathrm{O} 157: \mathrm{H} 7$ in primary cultures of resident peritoneal macrophages from outbred mice. A and B: E. coli O157:H7 susecpible to ampicillin (A. untreated macrophages, B. macrophages treated with $5 \mu \mathrm{g} / \mathrm{ml}$ of gentamicin). C and D: E. coli O157:H7 resistance to ampicillin (C. untreated macrophages, D. macrophages treated with $5 \mu \mathrm{g} / \mathrm{ml}$ of gentamicin). The error bars represent the standard deviation in an average of $\log _{10}$ intracellular E. coli O157:H7 from triplicate platting taken at each time.

Toll receptors enable the macrophage to recognize the microbial antigen, and by means of the TLR4 it can recognize the LPS (7). Moreover, TRL1-9 receptors that are identical in mice and humans can also recognize viral, bacterial, fungal and parasitic organisms (24).

The way in which the bacteria interacts with eukaryote cells in vitro (inside or outside the cells), was well studied. Antibiotics and bacteriophages which destroy the bacteria were used to eliminate the extracellular bacteria (20). Elsinghorst (4) reported that gentamicin, could kill the extracellular bacteria without affecting the intracellular ones; but recently Oyha et al. (19) demonstrated that this antibiotic might cross into the cellular membrane and affect the intracellular bacteria. Nevertheless, in our present work, $5 \mu \mathrm{g} / \mathrm{ml}$ of gentamicin was the concentration 
which eliminates the extracellular bacteria without affecting the intracellular ones.

In this study it turned out that, when the minimum effective dose of gentamicin is used, the intracellular bacteria do not change (Figs. 1 and 2). The bacteria isolated from peritoneal macrophage $72 \mathrm{~h}$ after infection, was about $10^{9} \mathrm{CFU}$ in all mice strains, so the gentamicin dose was not enough to eliminate the extracellular bacteria, $48 \mathrm{~h}$ after infection.

To understand the role of genetic and cellular agents in the innate immune system, the bacterial and the host factors which affect the nonopsonic phagocytosis were studied. Nonopsonic phagocytosis is the mechanism which participates in the killing process of the bacteria by the macrophage in the absence of any immunity serum (18). Whereas, the phagocytosis with opsonization mechanism is a different killing process characterized by the high percentage of bacterial death in presence of antibodies against the microbe (1). Differences in bacterial counts after infecting the macrophage without opsonization have not been observed suggesting that the macrophage genes differences do not affect the killing ability of $E$. coli $\mathrm{O} 157: \mathrm{H} 7$. Similar results were reported by Hamric et al. (5), who used macrophages from BALB/c, CD1, C57BL, C3H/ $\mathrm{HeG}$ and $\mathrm{C} 3 \mathrm{H} / \mathrm{HeN}$, and two strains of $E$. coli $\mathrm{K} 12$ one of which has $\mathrm{FimH}^{+}$and the other has only the recessive gene FimH. Moreover, Sukumaran et al. (22) observed that opsonization, with either complement proteins or antibody is not required for uptake and survival of the bacteria within the macrophages.

Pathogens have developed numerous strategies to escape the deleterious effect of phagocytosis by professional phagocytes among which are evading the phagocytosis, killing the phagocytes or surviving inside them (8). These are the most common processes reported so far, and some of such mechanisms include preventing recognition by phagocytic receptors or blocking the uptake by professional phagocytes. Experiments conducted by Celli et al., have demonstrated that the EPEC uptake by macrophages did not involve opsonindependent phagocytic receptors due to the inhibition of phosphatidylinositol (PI) 3-kinase-dependent F-actin rearrangements that are required for bacterial uptake (3). Furthermore, the latter process could exert inhibitory effects on macropinocytosis as reported by Murray et al., (16). In this context, our findings have accordingly shown that $E$. coli O157:H7 bacteria utilised a similar mechanism to survive and replicate inside the mice macrophages.

Results showed that E. coli $\mathrm{O} 157: \mathrm{H} 7$ not only extends the survival of murine infected macrophage, for all mice strains used in this study, but also renders them resistant to apoptosis. Moreover, the macrophages infected with E. coli $\mathrm{O} 157: \mathrm{H} 7$, have been revealed to be resistant to DNA fragmentation exposure. Our findings corroborate previous results that $E$. coli, induced cell proliferation of mammary cell cow and that OmpA E. coli K1 inhibit the apoptosis of human and murine infected macrophage
Long et al. (14), Sukumaran et al. (23). However, another study found that Stx 1 and Stx 2 produced by E. coli induced apoptosis of human mucosal epithelial cells that express the $\mathrm{Gb} 3$ receptor for the toxins (11).

Further studies ought to be achieved in order to understand the role of the resident peritoneal macrophage in bacterial killing mechanisms, and the interaction mechanisms between $E$. coli O157:H7 and the macrophages.

\section{ACKNOWLEDGMENTS}

The author thanks the Director General of AECS and the Head of the Molecular Biology and Biotechnology Department for their support. He thanks also Dr. M. Safi for his critical reading of this manuscript.

\section{RESUMO}

\section{Sobrevivência e multiplicação de Escherichia coli 0157:H7 no interior de macrófagos peritoniais de camundongos}

A multiplicação de Escherichia coli O157:H7 em macrófagos peritoniais residentes de quatro linhagens de camundongos (BALB/C, CD1, C57BL e Swiss) foi investigada. A capacidade bactericida dos macrófagos foi estimada através da avaliação de sua capacidade de internalizar E.coli (protegidos pela gentamicina) em ensaios de 2, 4, 24 e 48h. Observou-se que as características genéticas do hospedeiro não têm efeito significativo na capacidade dos macrófagos peritoniais eliminarem E. coli $\mathrm{O} 157: \mathrm{H} 7$.

Palavras-chave: Escherichia coli O157:H7, macrófagos, camundongos, gentamicina

\section{REFERENCES}

1. Aderem, A.; Underhill, D.M. (1999). Mechanisms of phagocytosis in macrophages. Annu. Rev. Immunol., 17, 593-623.

2. Beutin, L. (2006). Emerging enterohaemorrhagic Escherichia coli, causes and effects of the rise of a human pathogen. J. Vet. Med. B. Infect. Dis. Vet. Public Health., 53(7), 299-305.

3. Celli, J.; Olivier, M.; Finlay, B.B. (2001). Enteropathogenic Escherichia coli mediates antiphagocytosis through the inhibition of PI 3-kinase-dependent pathways. EMBO J., 20(6), 1245-1258.

4. Elsinghorst, E.A. (1994). Measurement of invasion by gentamicin resistance. Methods Enzymol., 236, 405-420.

5. Hamrick, T.S.; Havell, E.A.; Horton, J.R..; Orndorff, P.E. (2000). Host and bacterial factors involved in the innate ability of mouse macrophages to eliminate internalized unopsonized Escherichia coli. Infect. Immun., 68(1), 125-132.

6. Hamrick, T.S.; Diaz, A.H.; Havell, E.A; Horton, J.R.; Orndorff, P.E. (2003). Influence of Extracellular Bactericidal Agents on Bacteria within Macrophages. Infect. Immun., 71(2), 1016-1019.

7. Hirschfeld, M.; Weis, J.J.; Toshchakov, V.; Salkowski, C.A.; Cody, M.J.; Ward, D.C.; Qureshi, N.; Michalek, S.M.; Vogel, S.N. (2001). 
Signaling by Toll-like receptor 2 and 4 agonists results in differential gene expression in murine macrophages. Infect. Immun., 69(3), 1477-1482.

8. Goosney, D.L.; Celli, J.; Kenny, B.; Finlay; B.B. (1999). Enteropathogenic Escherichia coli Inhibits Phagocytosis. Infect. Immun., 67(2), 490-495.

9. Gordon, M.A.; Jack D.L.; Dockrell D.H.; Lee M.E.; Read R.C. (2005). Gamma Interferon Enhances Internalization and Early Nonoxidative Killing of Salmonella enterica Serovar Typhimurium by Human Macrophages and Modifies Cytokine Responses. Infect. Immun. 73(6), 3445-3452.

10. Greenberg, S. (1999). Modular components of phagocytosis. J. Leukoc Biol., 66(5), 712-717.

11. Jones, N.L.; Islur, A.; Haq, R.; Mascarenhas, M.; Karmali, M.A.; Perdue, M.H.; Zanke, B.W.; Sherman, P.M. (2000). Escherichia coli Shiga toxins induce apoptosis in epithelial cells that is regulated by the Bcl-2 family. Am. J. Physiol. Gastrointest. Liver. Physiol., 278(5), G811-G819.

12. Kyaw, C.M.; De Araujo, C.R.; Lima, M.R.; Gondim, E.G.; Brigido, M.M.; Giugliano, L.G. (2003). Evidence for the presence of a type III secretion system in diffusely adhering Escherichia coli (DAEC). Infect. Genet. Evol., 3(2), 111-117.

13. Li, K.; Feito, M.J.; Sacks, S.H.; Sheerin, N.S. (2006). CD46 (membrane cofactor protein) acts as a human epithelial cell receptor for internalization of opsonized uropathogenic Escherichia coli. J Immunol., 177(4), 2543-51.

14. Long, E.; Capuco, A.V.; Wood, D.L.; Sonstegard, T.; Tomita, G.; Paape, M. J.; Zhao, X. (2001). Escherichia coli induces apoptosis and proliferation of mammary cells. Cell. Death. Differ., 8(8), 808-816.

15. Murakami, J.; Kishi, K.; Hirai, K.; Hiramatsu, K.; Yamasaki, T.; Nasu, M. (2000). Macrolides and clindamycin suppress the release of Shiga-like toxins from Escherichia coli $\mathrm{O} 157: \mathrm{H} 7$ in vitro. Int. J. Antimicrob. Agents., 15(2), 103-109.
16. Murray, J.; Wilson, L.; Kellie, S. (2000). Phosphatidylinositol-3 kinase-dependent vesicle formation in macrophages in response to macrophage colony stimulating factor. J. Cell Sci., 1132, 337-348.

17. Norderhaug, I.N.; Johansen, F.E.; Schjerven, H.; Brandtzaeg, P. (1999). Regulation of the formation and external transport of secretory immunoglobulins. Crit. Rev. Immunol., 19(5-6), 481-508.

18. Ofek, I.; Goldhar, J.; Keisari, Y.; Sharon, N. (1995). Nonopsonic phagocytosis of microorganisms. Annu. Rev. Microbiol., 49, 239276.

19. Ohya, T.; Ohwada, S.; Kawashima, Y.; Tanahashi, Y.; Takahashi, T.; Ichikawa, H.; Tomizawa, N.; Morishita, Y. (1998). Efficacy of hypothermic perfusion using University of Wisconsin solution in extended hepatectomy with hepatic inflow occlusion in a canine model. J. Gastroenterol. Hepatol., 13(8), 781-785.

20. Oie, S.; Ishitobi, J.; Sawa, A.; Tomita, M.; Kamiya, A. (2004). In vitro bactericidal activity of antimicrobial agents against enterohaemorrhagic Escherichia coli. J. Antimicrob. Chemother. 54(5), 897-903.

21. Salvadori, M.R.; Valadares, G.F.; Leite, D.S.; Blanco, J.; Yamo, T (2003). Virulence factors of Escherichia coli isolated from calves with diarrhea in Brazil. B.J.M., 34, 230-235.

22. Sukumaran, S.K.; Shimada, H.; Prasadarao, N.V. (2003). Entry and Intracellular Replication of Escherichia coli $\mathrm{K} 1$ in Macrophages Require Expression of Outer Membrane Protein A. Infect. Immune. 71(10), 5951-5961.

23. Sukumaran, S.K.; Selvaraj, S.K.; Prasadarao, N.V. (2004). Inhibition of apoptosis by Escherichia coli $\mathrm{K} 1$ is accompanied by increased expression of $\mathrm{Bcl}[\mathrm{XL}]$ and blockade of mitochondrial cytochrome c release in macrophages. Infect. Immune., 72(10), 6012-6022.

24. Takeda, K.; Akira, S. (2005). Toll-like receptors in innate immunity. Int. Immunol., 17(1), 1-14.

25. Welinder-Olsson, C.; Kaijser, B. (2005). Enterohemorrhagic Escherichia coli (EHEC). Scand. J. Infect. Dis., 37(6-7), 405-16. 